\title{
Fruit Development, Pigmentation and Biochemical Properties of Wax Apple as Affected by Localized Application of $\mathrm{GA}_{3}$ under Field Conditions
}

\author{
Mohammad Moneruzzaman Khandaker*, Amru Nasrulhaq Boyce, Normaniza Osman, \\ Faruq Golam, M. Motior Rahman and Sofian-Azirun, M. \\ Institute of Biological Sciences; Faculty of Science; University of Malaya; 50603, Kuala Lumpur - Malaysia
}

\begin{abstract}
This study investigated the effects of gibberellin $\left(G A_{3}\right)$ on the fruit development, pigmentation and biochemical properties of wax apple. The wax apple trees were rubbing treated with 0, 20, 50 and $100 \mathrm{mgGA}_{3} / \mathrm{l}$ under field

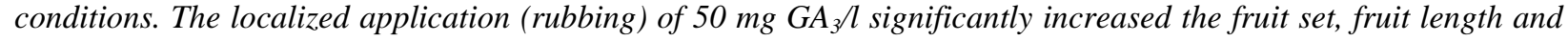

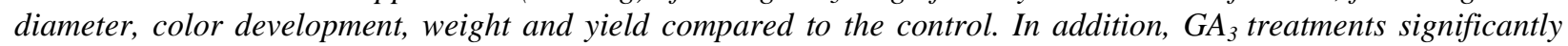

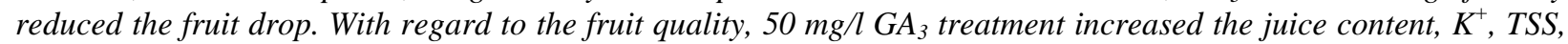
total sugar and sugar acid ratio of wax apple fruits. In addition, higher vitamin $C$, phenol, flavonoid, anthocyanin, carotene content, PAL and antioxidant activities were recorded in the treated fruits. There was a positive correlation between the peel colour and TSS content and between the PAL activity and anthocyanin formation in the

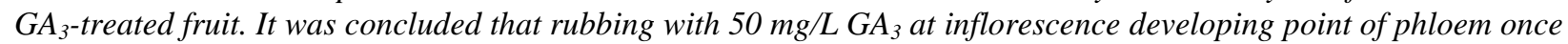
a week from the tiny inflorescence bud until the flower opening resulted in better yield and quality of wax apple fruits and could be an effective technique to safe the environment from excessive spray.
\end{abstract}

Key words: Fruit development, pigmentation, quality, $\mathrm{GA}_{3}$, wax apple

\section{INTRODUCTION}

The wax apple, or jambu air madu, as it is known in Malaysia, is a non-climacteric tropical fruit in the Myrtaceae family and is botanically known as Syzygium samarangense (Morton, 1987).Wax apple is widely cultivated throughout Malaysia, mainly in smallholdings ranging from 1 to 5 ha, with a total hectarage estimated at 1,500 ha in 2005 (Zen-hong et al. 2006). The pear-shaped fruits are usually pink, light red or red, but may be greenish-white or cream-colored, and are generally crisp, with a subtly sweet taste and aromatic flavor. The fruit pulp is a rich source of phenolics, flavonoids and several antioxidant compounds
(Moneruzzaman et al. 2012). In Malaysia, wax apple fruits are eaten raw with salt or cooked as a sauce and almost entire fruit is edible. The fruit can be used to treat high blood pressure and several inflammatory conditions, including sore throat, and can also be used as an antimicrobial, antiscorbutic, carminative, diuretic, and astringent (Rivera and Obón 1995).

It has been well documented that the size and quality of the fruits can be affected by certain horticultural cultural practices, such as the application of plant growth hormones (Wang et al. 2004). It has been reported that spray treatment of gibberellic acid $\left(\mathrm{GA}_{3}\right)$ increases the fruit set, growth and fruit size in wax apple fruits

*Author for correspondence: kmoneruzzaman@yahoo.com 
(Moneruzzaman et al. 2011). Basak et al. (1998) reported that $\mathrm{GA}_{3}$ increased the fruit firmness, fruit weight and yield and soluble solids. Wang et al. (2004) found that the application of $\mathrm{GA}_{3}$ and other growth regulators increased the sugar contents in various mandarin and sweet orange cultivars. Xiao et al. (2005) also reported that the application of growth regulators significantly reduced the acidity and increased vitamin-C contents of the citrus fruits. $\mathrm{GA}_{3}$ significantly promoted the biosynthesis of secondary metabolites and increased the phenol and flavonoids content in the apple (Zhou and Tan 1997). Montero et al. (1998) stated that $\mathrm{GA}_{3}$ treatment increased the anthocyanin content in addition to the enhancement of PAL and TAL activities in Fragaria ananossa fruits. Currently, there are no information how the $\mathrm{GA}_{3}$ affect the fruit quality of wax apple, an increasingly popular fruit in Asia. In this study, the effects of gibberellin, applied by rubbing, on the growth and development as well as the biochemical properties of the wax apple fruit was investigated under field conditions.

\section{MATERIALS AND METHODS}

\section{Experimental site and Treatment application}

The experiments were performed at a commercial farm in Banting at an elevation of approximately $45 \mathrm{~m}$ above sea level. The area under study has a hot and humid tropical climate. The soil in the orchard is peat, with a mean $\mathrm{pH}$ of of approximately 4.6 (Ismail et al. 1994). The experiments were conducted in three successive seasons in the same farm in Banting, Selangor, Malaysia in between 2009 to 2011. Twelve years old wax apple trees were selected for the study. The trees were planted in a $4.2 \mathrm{~m} \times 4.2 \mathrm{~m}$ hexagonal system and received the same horticultural management. Twenty-four trees were used in the experiments for each season. One hundred twenty uniform branches (five branches/tree) of about the same length and diameter, and approximately the same number of leaves were selected for the experiments. The experiment consisted of four treatments, including control, with six replications and a single tree was taken as an experimental unit. The inflorescence developing point of bark on the selected branches was rubbed with 20,50 and $100 \mathrm{mg} \mathrm{GA} / /$ and water (control) based on a Randomized Complete
Block Design (RCBD) with six replications each once a week until the flower opening.

\section{Measurement of physiological and biochemical parameters}

The percentage fruit drop was calculated by dividing the total number of fruit after anthesis minus the number of fruit at harvest with the total number of after anthesis. The chlorophyll and carotene content of fruit was measured by the methods described by Hendry and Price (1993). The fruit length, fruit diameter, and fruit growth were measured weekly with the aid of a Vernier calliper. The surface colour of each tagged fruit was determined at three different points using a standard colour chart (Minolta, Osaka, Japan) and expressed as a percentage of colour cover. The yield per treatment was recorded by weighing and counting the total number of fruits per treatment at the time of harvest. The total soluble solids (TSS) was evaluated at $25^{\circ} \mathrm{C}$ with an Atago 8469 hand refractometer (Atago Co. ltd., Japan) and expressed as ${ }^{\circ}$ Brix. The fruit juice was titrated with $0.1 \mathrm{M} \mathrm{NaOH}$ and the results were expressed in terms of percentage citric acid. The percentage was calculated using the Bhattarai and Gautam (2006) formula. The sugar acid ratio of the wax apple juice was given as the ratio of TSS/TA. Potassium content of fruit juice was determined by using a Cardy Potassium meter. The total soluble sugars was the determined according to the phenol-sulphuric method (Dubois et al. 1956). The total phenolic and total flavonoids content of fruits were determined by using the Folin-Ciocalteu and the aluminum chloride colorimetric assay. The total ascorbic acid (vit-C) content was determined using the method modified by Hashimoto and Yamafuji (2001). The total anthocyanin contents of the hydrophilic extracts were measured by the $\mathrm{pH}$ differential method (Rodriguez-Saona et al. 1999). The PAL activity in the crude enzyme extracts was assayed using the method as described by Zucker (1965) and expressed as nmol cinnamic acid yield. The DPPH free radical scavenging activity was determined as described by Yang et al. (2008), with minor modifications.

\section{Statistical analysis}

The experimental design was a Randomized Complete Block Design (RCBD) with six replications. The data obtained from three successive seasons were pooled and analyzed using MSTAT-C statistical software. One-way 
ANOVA was applied to evaluate the significant difference in the parameters studied in the different treatments. Least significant difference (Fisher's protected LSD) was calculated, following significant $\mathrm{F}$-test $(\mathrm{p}=0.05)$.

\section{RESULTS}

Fruit set, drop, weight and yield

Data in Table 1 showed that the fruit set was almost two times more in $50 \mathrm{mgGA}_{3} / \mathrm{l}$ treated branches compared to the control branches. The control branches showed the highest fruit drop
(46\%), with the least percentage of fruit dropped observed $(30 \%)$ in $20 \mathrm{mgGA}_{3} / 1$ treated branches, followed by 100 and $50 \mathrm{mg} \mathrm{GA}_{3} / \mathrm{l}$ treatments (Table 1). As shown in Table 1, all the $\mathrm{GA}_{3}$ treated branches in this study yielded the fruits with higher average fruit weight than the untreated control.

The yield, on a fruit weight basis, was almost three times higher in the $50 \mathrm{mg}$ GA3/l treated branches compared to the control. From the results, it could be seen that $50 \mathrm{mg} / \mathrm{lGA} 3$ treated branch produced the highest yield, followed by 100 and $20 \mathrm{mg} / \mathrm{l}$ treatment. Results were statistically significant between the treatments and control.

Table 1 - Effects of $\mathrm{GA}_{3}$ treatments on flowering, fruit development, yield and quality of wax apple.

\begin{tabular}{ccccccc}
\hline $\begin{array}{c}\text { Treatment } \\
(\mathrm{mg} / \mathrm{l})\end{array}$ & $\begin{array}{c}\text { Fruit set } \\
(\%)\end{array}$ & $\begin{array}{c}\text { Fruit drop } \\
(\%)\end{array}$ & Yield $(\mathrm{kg})$ & $\begin{array}{c}\text { Average fruit } \\
\text { weight }(\mathrm{g})\end{array}$ & $\begin{array}{c}\text { Fruit juice } \\
(\mathrm{mg} / \mathrm{l})\end{array}$ & $\begin{array}{c}\mathrm{K}^{+} \text {content } \\
(\mathrm{mg} / 100 \mathrm{~g})\end{array}$ \\
\hline $\mathrm{Control}$ & $29 \pm 4.40 \mathrm{c}$ & $46 \pm 6.00 \mathrm{~b}$ & $0.31 \pm 0.06 \mathrm{~d}$ & $52 \pm 2.17 \mathrm{c}$ & $71 \pm 2.08 \mathrm{a}$ & $18.5 \pm 1.85 \mathrm{~b}$ \\
$\mathrm{GA}_{3} 20$ & $35 \pm 3.84 \mathrm{~b}$ & $30 \pm 4.40 \mathrm{a}$ & $0.50 \pm 0.05 \mathrm{c}$ & $53 \pm 2.57 \mathrm{~b}$ & $78 \pm 1.76 \mathrm{a}$ & $32.3 \pm 7.53 \mathrm{a}$ \\
$\mathrm{GA}_{3} 50$ & $60 \pm 3.00 \mathrm{a}$ & $45 \pm 2.89 \mathrm{a}$ & $0.92 \pm 0.13 \mathrm{a}$ & $67 \pm 2.20 \mathrm{a}$ & $81 \pm 1.78 \mathrm{a}$ & $25.0 \pm 7.54 \mathrm{a}$ \\
$\mathrm{GA}_{3} 100$ & $48 \pm 7.10 \mathrm{~b}$ & $31 \pm 6.42 \mathrm{a}$ & $0.79 \pm 0.05 \mathrm{~b}$ & $61 \pm 2.97 \mathrm{a}$ & $79 \pm 1.75 \mathrm{a}$ & $29.0 \pm 7.23 \mathrm{a}$ \\
& $* *$ & $*$ & $* *$ & $*$ & $n \mathrm{~ns}$ & $* *$
\end{tabular}

Means ( \pm S.E) within the same column followed by the same letter, do not differ significantly according to LSD test at $\alpha=0.01 \mathrm{~ns}$, non-significant, *, ** Significant at 0.05 and 0.01 levels

\section{Fruit growth and color development}

As seen in Figures 1 and 2 , the $\mathrm{GA}_{3}$ treated branches exhibited higher fruit growth rate from the first week till the $7^{\text {th }}$ week, with regard to fruit length and diameter. At the $3^{\text {rd }}$ week, the fruit length was 4.90 and $4.39 \mathrm{~cm}$ in 50 and $100 \mathrm{mg}$ $\mathrm{GA}_{3} / 1$ treatments, respectively, whereas it was 2.46 $\mathrm{cm}$ in the control. This growth trend was observed through the whole fruit developmental period until the harvesting period. The fruit growth was significant between the treatments and control. Result showed that the fruit color development was greatly enhanced by the $\mathrm{GA}_{3}$ treatments at 50 and $100 \mathrm{mg} \mathrm{GA}_{3} / \mathrm{l}$ treated where the fruits exhibited the highest peel color development from day 14 till 28 (Fig. 3).

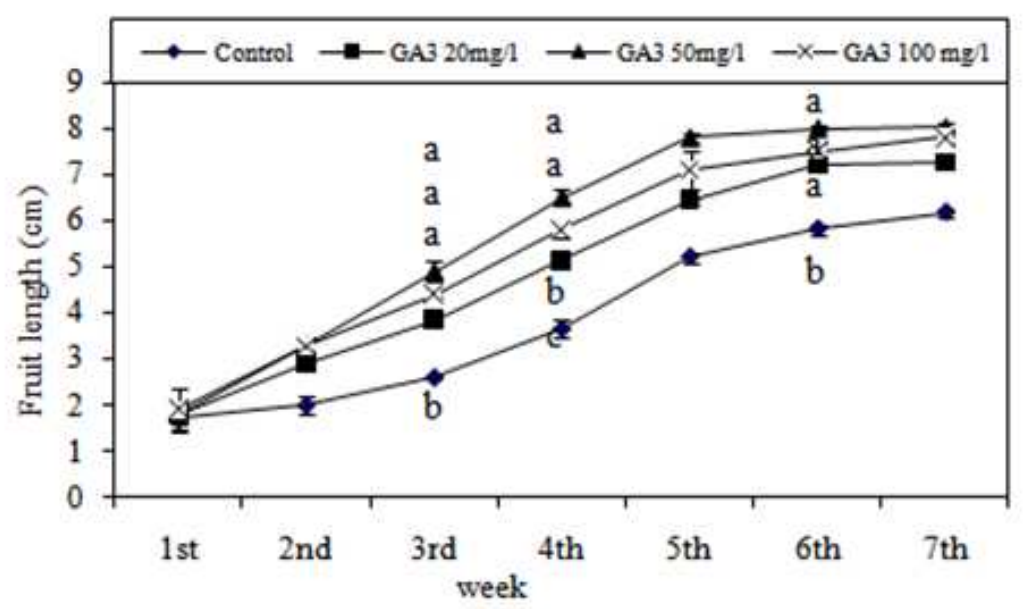

Figure 1 - Fruit growth (Length/week) as influenced by different concentrations of $\mathrm{GA}_{3}$. 


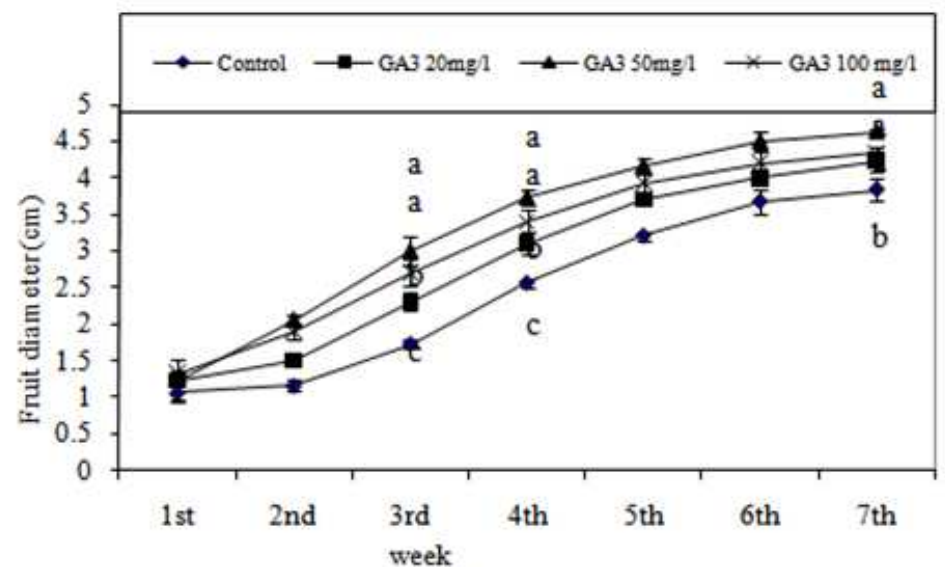

Figure 2 - Fruit growth (diameter/week) as influenced by different $\mathrm{GA}_{3}$.concentrations.

Furthermore, it was observed that on 14 (day after anthesis) the red colour of the fruits had already started to appear in the treated branches compared to the control fruits, which only started coloring one week later. At the $28^{\text {th }}$ day, the $50 \mathrm{mg} / \mathrm{l}$ treated fruits showed more or less $99 \%$ red color, whereas the control had only 35\% (Fig. 3). Significant difference was observed in the peel color development between different $\mathrm{GA}_{3}$ treatments and control.

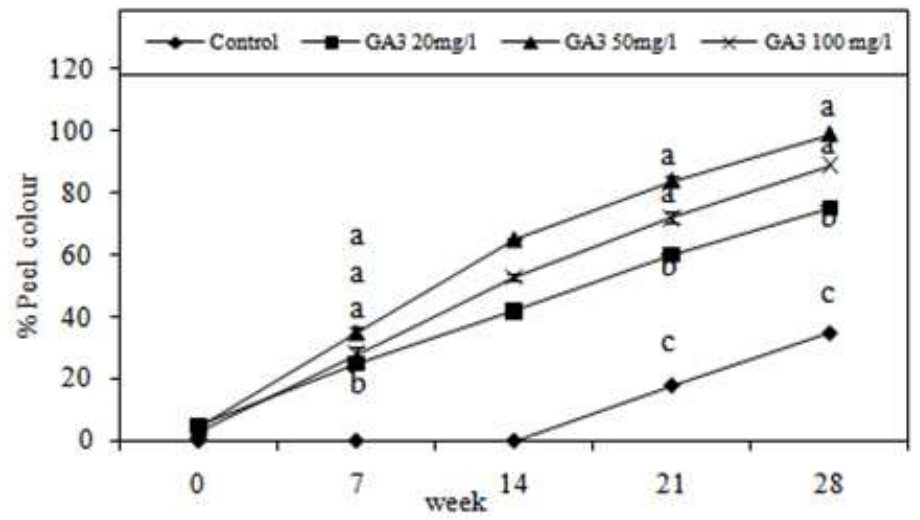

Figure 3 - The effect of different treatments of $\mathrm{GA}_{3}$.on peel colour of wax apple fruits after anthesis.

\section{Fruit juice and potassium content}

The fruits of $\mathrm{GA}_{3}$ treated branches produced higher amount of fruit juice, although their differences were not statistically significant (Table 1).The treatments of $\mathrm{GA}_{3}$ produced significant effect in the case of $\mathrm{K}^{+}$content in the wax apple fruits (Table 1). Results showed that the highest $\mathrm{K}^{+}$content in the fruit juice was higher in 20 $\mathrm{mgGA}_{3} / \mathrm{l}$ treated fruits, followed by 100 and $50 \mathrm{mg}$ $\mathrm{GA}_{3} /$ l treatments; the control produced the lowest amount of $\mathrm{K}^{+}$content.

Titrable acidity (TA) and sugar acid ratio The results for the TA experiments indicated that the titrable acidity was significantly affected by the $\mathrm{GA}_{3}$ application (Table 2). The lowest amount of TA $(0.64 \%)$ was observed with the $50 \mathrm{mgGA}_{3} / \mathrm{l}$ treatment, followed by the 10 and $20 \mathrm{mg} \mathrm{GA} / 1$ treatments. The highest amount of the titrable acidity $(0.73 \%)$ was observed in the control. The result showed that the sweetness index (sugar acid ratio) of the fruits was significantly enhanced by the $\mathrm{GA}_{3}$ treatments (Table 2).

The highest increased sugar acid ratio $(78 \%)$ was recorded in $50 \mathrm{mgGA}_{3} / 1$ treatment followed by the 100 and $20 \mathrm{mg} \mathrm{GA} / 1$ treatments with increases of $69 \%$ and $45 \%$, respectively, relative to the control. 
Table 2 - Effect of $\mathrm{GA}_{3}$ treatments on biochemical parameters of wax apple under field conditions.

\begin{tabular}{|c|c|c|c|c|c|c|}
\hline $\begin{array}{l}\text { Treatment } \\
(\mathrm{mg} / \mathrm{L})\end{array}$ & TSS ( ${ }^{\circ}$ Brix) & $\begin{array}{c}\text { Titrable } \\
\text { acidity }(\%)\end{array}$ & $\begin{array}{l}\text { TSS/acidity } \\
\text { ratio }\end{array}$ & $\begin{array}{l}\text { Total sugar } \\
\text { (g /100 g pulp) }\end{array}$ & $\begin{array}{l}\text { Flavonoids } \\
(\mathrm{mg} / 100 \mathrm{~g})\end{array}$ & $\begin{array}{c}\text { Total phenols } \\
(\mathrm{mg} \mathrm{GAE} / 100 \mathrm{~g})\end{array}$ \\
\hline Control & $6.70 \pm 0.3 b$ & $0.73 \pm 0.04 a$ & $9.18 \pm 1.5 b$ & $3.65 \pm 0.47 b$ & $18.5 \pm 0.5 b$ & $0.44 \pm 0.08 \mathrm{~d}$ \\
\hline $\mathrm{GA}_{3} 20$ & $9.07 \pm 0.3 \mathrm{a}$ & $0.68 \pm 0.03 b$ & $13.3 \pm 1.7 \mathrm{a}$ & $5.57 \pm 0.25 a$ & $40.0 \pm 2.0 \mathrm{a}$ & $0.68 \pm 0.15 b$ \\
\hline $\mathrm{GA}_{3} 50$ & $10.5 \pm 0.6 \mathrm{a}$ & $0.64 \pm 0.04 b$ & $16.4 \pm 1.9 \mathrm{a}$ & $6.24 \pm 0.23 a$ & $45.0 \pm 1.2 \mathrm{a}$ & $0.88 \pm 0.05 a$ \\
\hline $\mathrm{GA}_{3} 100$ & $\begin{array}{c}10.1 \pm 0.5 \mathrm{a} \\
* *\end{array}$ & $\begin{array}{c}0.65 \pm 0.03 b \\
*\end{array}$ & $\begin{array}{c}15.5 \pm 1.6 \mathrm{a} \\
* *\end{array}$ & $\begin{array}{c}5.82 \pm 0.32 \mathrm{a} \\
* *\end{array}$ & $\begin{array}{c}37.9 \pm 1.7 \mathrm{a} \\
* *\end{array}$ & $\begin{array}{c}0.74 \pm 0.09 \mathrm{a} \\
* *\end{array}$ \\
\hline
\end{tabular}

Mean \pm S.E ( $\mathrm{n}=6$ ) within the same column followed by the same letter, do not differ significantly according to LSD test at $\dot{\alpha}=0.01 \mathrm{~ns}$, non-significant $*, * *$ Significant at 0.05 and 0.01 level.

Total soluble solids (TSS), total sugar and correlation between peel color and TSS

Significant variations were recorded in the case of TSS content in the wax apple pulp between the fruits of different $\mathrm{GA}_{3}$ treatments (Table 2). The highest TSS value $\left(11.50{ }^{\circ} \mathrm{Brix}\right)$ was recorded in $50 \mathrm{mgGA}_{3} / 1$ treated fruit, followed by 100 and 20 $\mathrm{mgGA}_{3} / \mathrm{l}$ treatments, respectively, while the minimum was recorded in the control treatment. The result showed that $\mathrm{GA}_{3}$ treatments had a significant effect on the total sugar content of the wax apple fruit. The highest amount of total sugar content $(6.24 \mathrm{~g})$ was recorded in $50 \mathrm{mgGA}_{3} / \mathrm{l}$ treatment, followed by 100 and $20 \mathrm{mgGA}_{3} / 1$ treatments with 5.82 and $5.57 \mathrm{~g}$, respectively, whereas untreated control fruits showed the lowest sugar content of $3.65 \mathrm{~g}$ (Table 2). The peel color of $50 \mathrm{mgGA}_{3} / 1$ treated fruits had a strong positive correlation $\left(\mathrm{R}^{2}=0.97\right)$ with the TSS ( ${ }^{\circ}$ Brix) content of fruit juice (Fig. 4). The TSS content increased simultaneously with the peel color of the fruits.

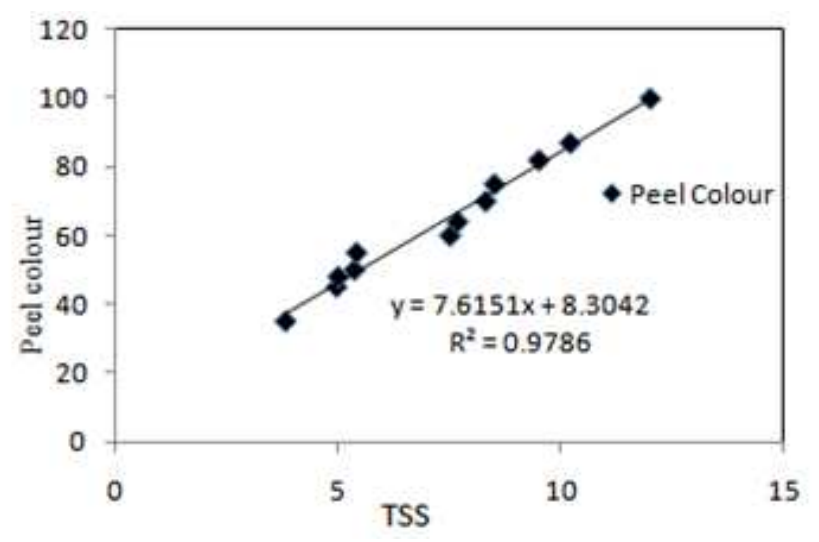

Figure 4 - Correlation between peel color and TSS content of wax apple fruits affected by 50mg/l $\mathrm{GA}_{3}$ treatment.

\section{Total flavonoids and phenolics}

The localized application of the various concentrations of $\mathrm{GA}_{3}$ had significant effects on the polyphenolic compounds (flavonoid and phenol) of the wax apple fruits (Table 2). The highest content of flavonoid $(45.0 \mathrm{mg} / 100 \mathrm{~g})$ was recorded in $50 \mathrm{mg} \mathrm{GA} / 1$ treated fruits, followed by the 20 and $100 \mathrm{mg} \mathrm{GA} / 1$ treatment, with flavonoid contents of 40.0 and $37.9 \mathrm{mg} / 100 \mathrm{~g}$, respectively. The control fruits had less than the treated fruits. As shown in Table 2, the fruits from $50 \mathrm{mgGA}_{3} / 1$ treated branches had the highest amount of phenol (0.88 mgGAE /100g), followed by 100 and $20 \mathrm{mgGA}_{3} / 1$ treated fruits with 0.74 and $0.68 \mathrm{mgGAE} / 100 \mathrm{~g}$, respectively, while the control fruits had the lowest phenol content $(0.44$ mgGAE /100g).

Vitamin C, Chlorophyll, anthocyanin and carotene content

In this study, $\mathrm{GA}_{3}$ application significantly affected the vit-C content of wax apple fruits (Table 3). The highest vit-C content $(6.5 \mathrm{mg} / 100$ g) was recorded in $50 \mathrm{mgGA}_{3} / 1$ treated-fruits, followed by the fruits treated with 20 and 100 $\mathrm{mg} / \mathrm{L} \mathrm{GA}_{3}$, with a vit-C content of 6.2 and 5.9 
$\mathrm{mg} / 100 \mathrm{~g}$, respectively. The lowest amount of vit$\mathrm{C}(5.3 \mathrm{mg} / 100 \mathrm{~g})$ was recorded in the control fruit. The chlorophyll content of the ripening wax apple skin was also recorded in this study. The results showed that $\mathrm{GA}_{3}$ application significantly reduced the chlorophyll content in the fruits. The highest chlorophyll content $(0.65 \mathrm{mg} / \mathrm{l})$ was observed in the control, followed by the amounts recorded in the 20 and $100 \mathrm{mgGA}_{3} / \mathrm{l}$ treatments.

The lowest amount $(0.32 \mathrm{mg} / \mathrm{l})$ was recorded in 50 $\mathrm{mgGA}_{3} / 1$ treated fruits (Table 3 ). The application of $50 \mathrm{mg} \mathrm{GA} / 1$ resulted in the highest carotene content followed by 100 and $20 \mathrm{mgGA}_{3} / 1$ treatments. The application of $\mathrm{GA}_{3}$ had a significant effect on the anthocyanin content of wax apple fruits (Table 3). Anthocyanin content enhanced in fruits treated with up to $50 \mathrm{mgGA}_{3} / \mathrm{l}$ treatment but thereafter decreased. The highest amount of anthocyanin was observed in 50 $\mathrm{mgGA}_{3} / 1$ treated fruits followed by 20 and 100 $\mathrm{mgGA}_{3} / 1$ treatments.

Table 3 - Effect of $\mathrm{GA}_{3}$ treatments on vit-C, leaf chlorophyll, carotenoids and anthocyanin of wax apple.

\begin{tabular}{cccccc}
\hline $\begin{array}{c}\text { Treatment } \\
(\mathrm{mg} / \mathrm{l})\end{array}$ & $\begin{array}{c}\text { Vit-C } \\
(\mathrm{mg} / 100 \mathrm{~g})\end{array}$ & $\begin{array}{c}\text { Chlorophyll } a \\
\text { fruit }(\mathrm{mg} / \mathrm{l})\end{array}$ & $\begin{array}{c}\text { Carotenoid } \\
(\mu \mathrm{g} / \mathrm{g})\end{array}$ & $\begin{array}{c}\text { Anthocyanin } \\
(\mathrm{mg} / \mathrm{L})\end{array}$ & $\begin{array}{c}\text { DPPH assay } \\
(\% \text { inhibition })\end{array}$ \\
\hline Control & $5.3 \pm 0.05 \mathrm{c}$ & $0.65 \pm 0.05 \mathrm{a}$ & $06.54 \pm 0.24 \mathrm{~b}$ & $2.43 \pm 0.20 \mathrm{c}$ & $50 \pm 2.52 \mathrm{~b}$ \\
$\mathrm{GA}_{3} 20$ & $6.2 \pm 0.07 \mathrm{~b}$ & $0.43 \pm 0.01 \mathrm{~b}$ & $09.92 \pm 0.36 \mathrm{a}$ & $4.02 \pm 0.31 \mathrm{~b}$ & $75 \pm 3.40 \mathrm{a}$ \\
$\mathrm{GA}_{3} 50$ & $6.5 \pm 0.10 \mathrm{a}$ & $0.32 \pm 0.03 \mathrm{c}$ & $10.90 \pm 0.20 \mathrm{a}$ & $4.60 \pm 0.37 \mathrm{a}$ & $83 \pm 3.50 \mathrm{a}$ \\
$\mathrm{GA}_{3} 100$ & $5.9 \pm 0.09 \mathrm{~b}$ & $0.34 \pm 0.01 \mathrm{~b}$ & $10.01 \pm 0.12 \mathrm{a}$ & $3.60 \pm 0.28 \mathrm{~b}$ & $79 \pm 4.30 \mathrm{a}$ \\
& $*$ & $* *$ & $* *$ & $* *$ & $* *$
\end{tabular}

Mean \pm S.E $(n=6)$ within the same column followed by the same letter, do not differ significantly according to LSD test at $\dot{\alpha}=0.01 \mathrm{~ns}$, non-significant, *, ** Significant at 0.05 and 0.01 levels.

Antioxidant content and Correlation between phenolics and antioxidant activity

The DPPH radical scavenging activity measured in the wax apple fruit extracts was affected by the $\mathrm{GA}_{3}$ (Table 3). Results showed that the $\mathrm{IC}_{50}$ of the DPPH radical scavenging activity increased with $\mathrm{GA}_{3}$ application. The DPPH radical scavenging activity increased up to $66 \%$ fruit extracts from the
$50 \mathrm{mg} \mathrm{GA} / 1$ treatment, while the activity in the control was only $50 \%$ (Table 3 ). Figure 5 shows the relationship between antioxidant capacity and the phenolic contents of wax apple fruit. A high correlation $\left(\mathrm{R}^{2}=0.86\right)$ was observed between the total phenolic content and DPPH measurements in the $50 \mathrm{mg} \mathrm{GA}_{3} / 1$ treated fruits.

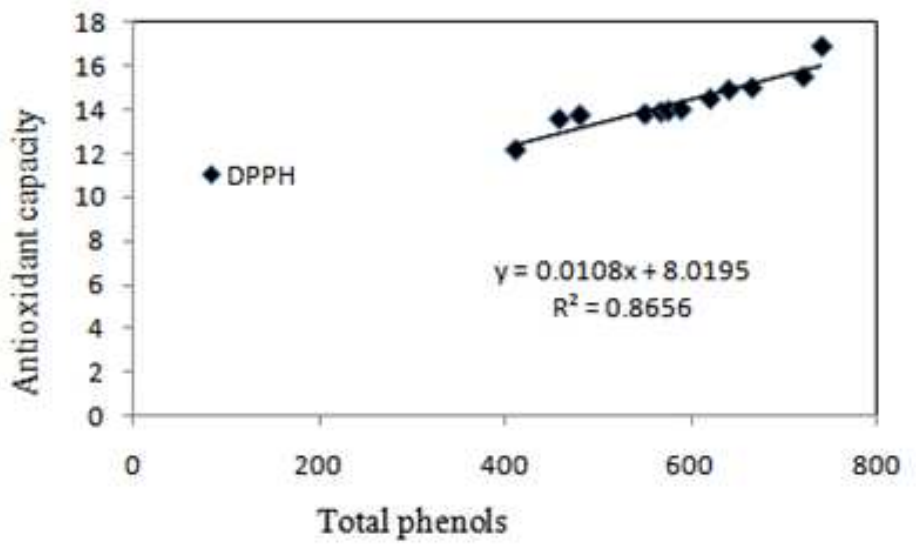

Figure 5 - Regression analysis of antioxidant capacity and total phenols of wax apple fruits.

PAL activity and correlation between PAL and anthocyanin formation

It was observed that $\mathrm{GA}_{3}$ treatment had a significant effect on the phenylalanine ammonia lyase (PAL) activity (Fig. 6). After $30 \mathrm{~min}$ of incubation, the PAL activity expression of the cinnamic acid yield was the highest $(36.91 \mathrm{nmol}$ min $^{-1} \mathrm{mg}$ protein ${ }^{-1}$ ), whereas the control fruits 
produced the lowest amount of cinnamic acid $\left(21.37 \mathrm{nmol} \mathrm{min}^{-1} \mathrm{mg}\right.$ protein $\left.{ }^{-1}\right)$.

A high degree of positive correlation $(\mathrm{R} 2=0.88)$ was observed between the PAL activity and anthocyanin formation in the treated ripening fruits (Fig.7).

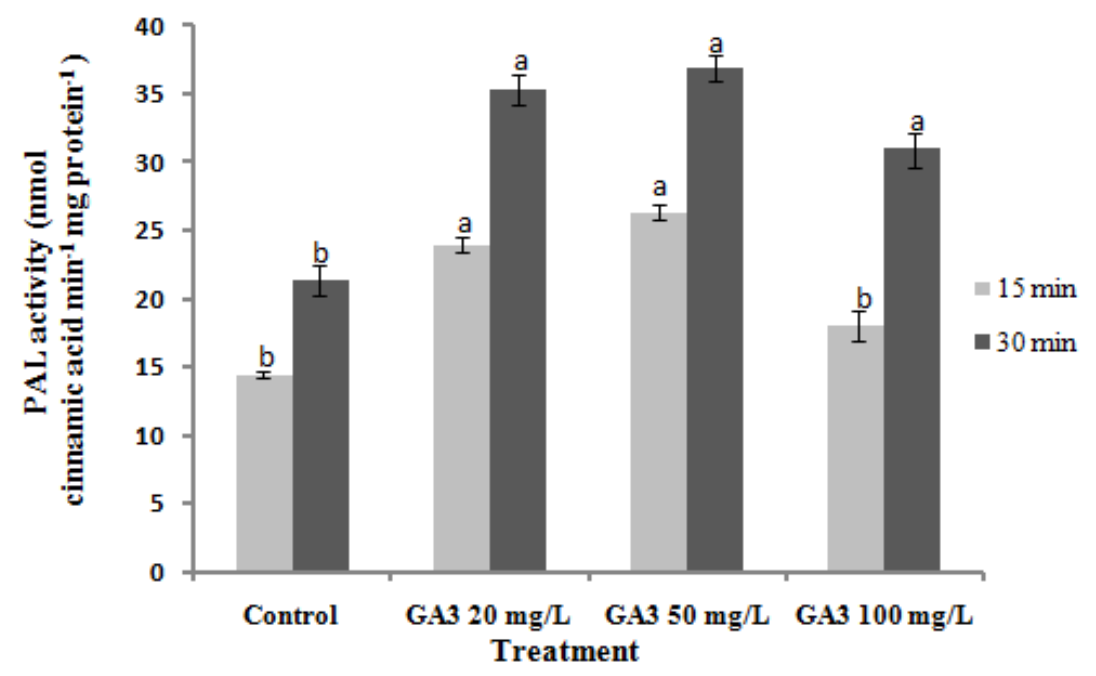

Figure 6 - The effect of $\mathrm{GA}_{3}$ treatment on PAL activity of ripening wax apple fruits. Bars indicate $( \pm$ S.E).

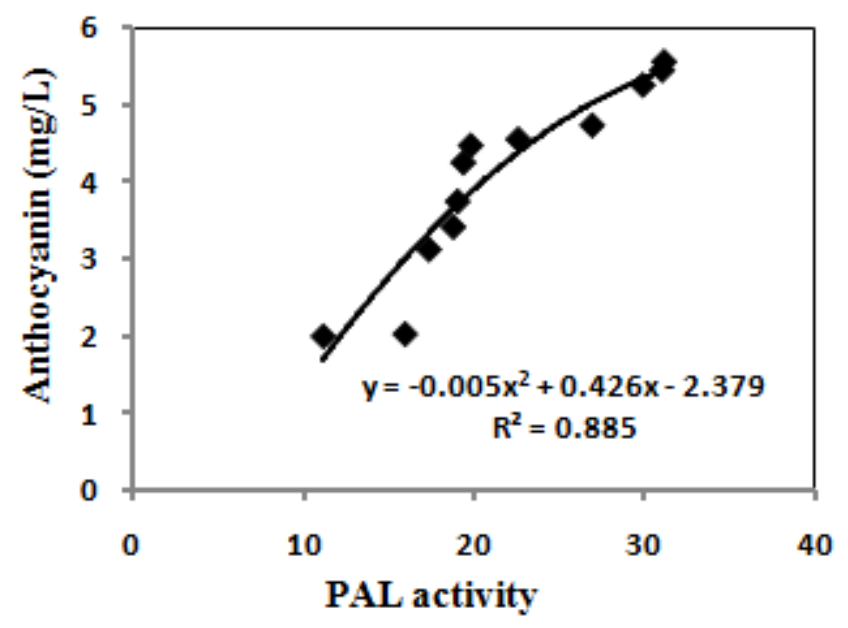

Figure 7 - Correlation between PAL activity (nmol-cinnamic acid $\min ^{-1} \mathrm{mg}$ protein ${ }^{-1}$ ) and anthocyanin content in $50 \mathrm{mg} / \mathrm{L} \mathrm{GA}_{3}$ treated wax apple fruit.

\section{DISCUSSION}

Results showed that all the $\mathrm{GA}_{3}$ treated branch posted significantly higher fruit set values compared to the control. These results were in agreement with the findings of Moneruzzaman et al. (2011) who reported that $\mathrm{GA}_{3}$ as a spray treatment increased the fruit set, number of fruit and growth in the wax apple. In this study, positive effects of $\mathrm{GA}_{3}$ on the fruit drop on the wax apple fruits were also found. Similar observations in citrus fruit were also reported by Almeida et al. (2004). Several previous studies have reported that the $\mathrm{GA}_{3}$ treatments could increase the fruit weight, peel thickness and fruit diameter of Valencia oranges (Almeida et al. 2004). Results for the fruit weight and yield were in agreement with that of 
Basak et al. (1998) who observed that $\mathrm{GA}_{3}$ significantly influenced the fruit weight as well as the yield in cherry. The treated fruits grew at a faster rate and were larger than the untreated control fruits. Singh and Lal (1980) also described a similar trend in Yu Her Pau' litchi over two years in Taiwan. They also stated that the $\mathrm{GA}_{3}$ treatment increased the fruit and aril weight. The development of red pigmentation in the peels of maturing wax apple fruits was the result of a massive accumulation of anthocyanin content and chlorophyll degradation during the maturation period (Zhang et al. 2008). The present results for the peel color development were in agreement with those of Ganji and Mokhtarian (2006) who reported that the application of $\mathrm{GA}_{3}$ increased the color of the fruits.

Fruit juice content, which is related to fruit size, is an important parameter in industrial processing. In this study, $\mathrm{GA}_{3}$ treatment showed a positive effect on the juice content of wax apple fruits. These results were in agreement with that of Wang et al. (2004) who reported that the application of $\mathrm{GA}_{3}$ significantly increased the juice percentage in various citrus species. It has been reported that potassium regulates the translocation of photosynthates, protein synthesis, ionic balance and plant stomatal opening and also known as a quality nutrient because of its important effects on fruit quality factors such as size, shape, color, taste, shelf life and fiber quality (Almeselmani et al. 2010). The present results suggested that $\mathrm{GA}_{3}$ had positive effects on $\mathrm{K}^{+}$content in the fruits. In this study, $\mathrm{GA}_{3}$ treatments produced significant effects on the TSS content of the wax apple. These findings were in agreement with the Basak et al. (1998) who reported that auxin and gibberellins could significantly increase the total soluble solids contents of the fruit in sweet cherry. The TSS content of tomato fruits increased with gradual advancement of fruit maturity and the highest TSS was recorded in fully ripened tomatoes (Moneruzzaman et al. 2008). The present results for the correlation of the peel color with TSS were in agreement with Moneruzzaman et al. (2009). The argument for this is that the TSS is indicative of higher sugar content in the fruits and this in turn supplies the energy for the synthesis of the red color pigments found in these fruits, as ripening sets in.

In the present study, $\mathrm{GA}_{3}$ application significantly reduced the titrable acidity content in the wax apple fruits. Thakur et al. (1996) similarly reported that the titrable acidity was significantly reduced with $\mathrm{GA}_{3}$ and auxin application. Wahdan et al. (2011) reported that $\mathrm{GA}_{3}$ treatments significantly increased the TSS, sugar acid ratio and total sugar content of mango. Similarly, in this study significant changes in the sugar acid ratio due to growth regulator application in wax apple fruits were also recorded. In fact, the sugar acid ratio could be the key factor affecting the quality of wax apple under tropical climates. Accordingly, in the current study, $\mathrm{GA}_{3}$ treatments produced a significant effect on total sugar content of wax apple fruits. These results were similar to the results of Wang et al. (2004) who found that the application of 2, 4-D, $\mathrm{GA}_{3}$ and some other growth regulators increased the sugar contents in various mandarin and sweet orange cultivars. In the present work, $\mathrm{GA}_{3}$ treatments clearly had a significant effect on the total flavonoid and phenolic content of the wax apple fruits. Results also showed that the phenolic content positively correlated with the antioxidant activity in the $\mathrm{GA}_{3}-$ treated fruits. These results were in agreement with the findings of Pourmorad et al. (2006) who reported that the extracts of $M$. officinalis containing the highest amounts of flavonoid and phenolic compounds exhibited the maximum antioxidant activity.

Vit-C content in the fruits varies among the crop species and is affected by the environmental factors, time of fruit harvesting, plant vigor, the age of the plant and the use of growth regulators. In this study, $\mathrm{GA}_{3}$ treatments showed a significant effect on the vit-C content in the wax apple. This finding was in agreement with the results of Wahdan et al. (2011) that 'Succary Abiad' mango trees sprayed with $\mathrm{GA}_{3}$ two months after the fullbloom at $40 \mathrm{ppm}$ exhibited significant increases in the vit- $\mathrm{C}$ contents. During the ripening, there is degradation of chlorophyll which is accompanied by the synthesis of other pigments, usually either anthocyanin or carotenoids. In this study, it was observed that chlorophyll loss gradually took place with the $\mathrm{GA}_{3}$ application at color turning stage. Similar results were reported by Perez et al. (1993), who found that the plant growth regulator methyl jasmonate promoted the chlorophyll degradation of the skin of Golden Delicious apple fruit.

The positive effects of $\mathrm{GA}_{3}$ on PAL and TAL of Fragaria ananossa fruits have also been noted previously (Montero et al. 1998). This study showed that $\mathrm{GA}_{3}$ treatment enhanced the PAL 
enzyme activities in the fruits, which might stimulate the anthocyanin accumulation. Carotenoids are the precursors of vitamin $\mathrm{A}$ and those commonly occurring in the nature include, $\alpha$, $\beta$ and $\gamma$ carotene, lycopene and cryptoxanthin (Goodwin 1986). Results showed that $\mathrm{GA}_{3}$ treatment significantly increased the anthocyanin and carotene content in the fruits. These results concurred with the findings of Roussos et al. (2009) who observed that the anthocyanin content in the strawberry fruit increased significantly when the plants were treated with $\mathrm{GA}_{3}$. It suggested that $\mathrm{GA}_{3}$ could also play a role in the accumulation of pigments in the fruits. The present results showed that the fruits treated with the $\mathrm{GA}_{3}$ exhibited higher antioxidant capacity than the control fruits. These findings were consistent with the results of Klessig and Malamy (1994) who reported that $\mathrm{GA}_{3}$ significantly promoted the biosynthesis of secondary metabolites in the fruit with the highest antioxidant activity.

\section{CONCLUSION}

From the above results, it could be concluded that the localized application of the $\mathrm{GA}_{3}$, particularly, $50 \mathrm{mg} \mathrm{GA}_{3} / \mathrm{l}$ could stimulate the fruit growth and pigmentation as well as the biochemical properties of wax apple fruit. The treatment with $50 \mathrm{mg}$ $\mathrm{GA}_{3} / 1$ increased the fruit set, growth, size, juice and $\mathrm{k}^{+}$content; in addition, TSS, total sugar, sugar acid ratio, vit-C, anthocyanin, carotenoid, phenolics and flavonoids and antioxidant activity in the fruits were also significantly increased. The $\mathrm{GA}_{3}$ treatments also significantly reduced the chlorophyll and titrable acidity in the fruits, which also showed positive correlations between the peel color and TSS, between the phenolic compounds and antioxidant activity and between the PAL activity and anthocyanin formation. Finally, it could be concluded that $50 \mathrm{mgGA}_{3} / \mathrm{l}$ treatment was promising for enhancing the fruit development, pigmentation and improving the biochemical properties of the wax apple fruits under the field conditions.

\section{ACKNOWLEDGEMENTS}

This research was supported by grant from University of Malaya, Kuala Lumpur, 50603, Malaysia (Project No.RG002/09BIO).

\section{REFERENCES}

Almeselmani M, Pant RC, Singh B. Potassium Level and Physiological Response and Fruit Quality in Hydroponically Grown Tomato. Int J Vegetable Sci. 2010; 16(1):85- 99.

Almeida I, Leite IM, Rodrigues JD, Ono EO. Application of plant growth regulators at pre-harvest for fruit development of 'PERA' oranges. Braz Arch Biol Technol. 2004; 47: 658-662.

Basak A, Rozpara E, Grzyb Z. Use of bioregulators to reduce sweet cherry tree growth and to improve fruit quality. Acta Hort. 1998; 468: 719-723.

Davies FS, Zalman, G. Gibberellic acid, fruit freezing, and post-freeze quality of Hamlin oranges. Hort. Tech. 2006; 16: 301-305.

Dubois MK, Gils JK, Hanniton PA, Robes SF. Use of phenol reagent for the determination of total sugar. Anal Chem. 1956; 28:350-356.

Ganji EM, Mokhtarian A. Delaying Apricot (cv. Shahroudi) Flower Induction by Growth Regulators Application. J App Sci. 2006; 6: 266-269.

Goodwin TW. Metabolism, nutrition and functions of carotenoids. Anal Rev Nutr. 1986; 6: 273-97.

Hendry GAF, Price AH. Stress indicators: chlorophylls and carotenoids. In: Hendry, G.A.F., Grime, J.P. (Eds.), Methods in Comparative Plant Ecology. Chapman \& Hall, London; 1993. p. 148-52.

Klessig DF, Malamy J. The salicylic acid signal in plants. Plant Mol Biol. 1994; 26:1439-1458.

Lim PO, Woo HR, Nam HG. Molecular genetics of leaf senescence in Arabidopsis. Trends in Plant Sci. 2003; 6: 272-278.

Moneruzzaman KM, Hossain ABMS, Sani W, Saifuddin M. Alenazi M. Effect of harvesting and storage conditions on the post harvest quality of tomato (Lycopersicon esculentum Mill) cv. Roma VF. Aus J Crop Sci. 2009; 3(2):113-121.

Moneruzzaman KM, Hossain ABMS, Normaniza O, and Boyce AN. Growth, yield and quality responses to $\mathrm{GA}_{3}$ of wax apple Syzygium samarangense, Afr J Biotechnol. 2011; 10 (56):11911-11918. 
Moneruzzaman KM, Boyce AN, and Normaniza O. The Influence of Hydrogen Peroxide on the Growth, Development and Quality of Wax Apple (Syzygium samarangense, var. jambu madu) Fruits, Plant Physiol Biochem. 2012; 53:101-110.

Moneruzzaman KM, Hossain ABMS, Sani W, Saifuddin M. Effect of Stages of Maturity and Ripening Conditions on the Biochemical Characteristics of Tomato. Am J Biochem Biotechnol. 2008; 4(4): 336-344.

Montero TE, Molla' Martı́n-Cabrejas MA, LopezAndre'u FJ. Effects of gibberellic acid $\left(\mathrm{GA}_{3}\right)$ on strawberry PAL (phenylalanine ammonia-lyase) and TAL (tyrosine ammonia-lyase) enzyme activities. $J$ Sci Food Agric. 1998; 77: 230-234.

Perez AG, Sanz C, Richardson DG, Olias JM. Methyl jasmonate vapor promotes beta-carotene synthesis and chlorophyll degradation in Golden Delicious apple peel, J Plant Growth Regul. 1993; 12: 163-168.

Pourmorad FS, Hosseinimehr J, Shahabimajd N. Antioxidant activity, phenol and flavonoid contents of some selected Iranian medicinal plants. Afr $J$ Biotechnol. 2006; 5:1142-1145.

Rodriguez-Saona LE, Giusti MM. Wrolstad RE, Color and pigment stability of red radish and red-fleshed potato anthocyanins in juice model systems. J Food Sci. 1999; 64: 451-456.

Rivera D, Obón C. The ethno pharmacology of Madeira and Porto Santo islands, a review. J Ethnopharmacol. 1995; 46:73-93.

Roussos PA, Denaxa NK, Damvakaris T. Strawberry fruit quality attributes after application of plant growth stimulation compounds. Sci Hort. 2009; 119:138-146.

Singh US, Lal RK. Influence of growth regulators on setting, retention, and weight of fruits in two cultivars of litchi. Sci Hort. 1980; 12:321-326.
Tadesse T, Hewett EW, Nichols MA, Fisher KJ. Changes in physicochemical attributes of sweet pepper cv. Domino during fruit growth and development. Sci Hort. 2002; 93(2): 91-103.

Thakur BR, Singh RK, Nelson P. Quality attributes of processed tomato products: A review. Food Res. Int. 1996; 12:375-401.

Wang CF, You YF, Chen XS, Wang J. Adjusting effect of brassinolide and $\mathrm{GA}_{4}$ on the orange growth. Acta Agril. 2004; 26:759-762.

Wahdan MT, Habib SE, Bassal MA, Qaoud EM. Effect of some chemicals on growth, fruiting, yield and fruit quality of "SuccaryAbiad" mango cv. J Amer Sci. 2011; 7: 651-658.

Xiao JX, Peng S, Hua HP, Jiang LH. Effects of calcium nitrate and IAA on calcium concentration and quality of Satsuma mandarin fruit. J Fruit Sci. 2005; 22: 211215.

Zen-hong S, Meon Z, Tirtawinata R, Thanarut C. Wax apple production in selected tropical Asian countries. ISHS, Acta Hort. 2006; 773: 161-164.

Zhang W, Li X, Zheng J, Wang G, Sun C, Ferguson I, Chen K. Bioactive components and antioxidant capacity of Chinese bayberry (Myricarubra Sieb. and Zucc.) fruit in relation to fruit maturity and postharvest storage. European Food Res. Technol. 2008; 227:1091-1097.

Zhou Y. Tan X. Mechanism of blackheart development induced by low temperature and gibberellic acid in pineapple fruit. Acta Hort. 1997; 425: 587-593.

Received: September 26, 2011; Revised: March 06, 2012; Accepted: September 21, 2012. 